Brit. J. Ophthal. (1959) 43, 192.

\title{
OBITUARY
}

\section{JAMES ANDREW CRAIG}

James Craig died in Belfast on November 26, 1958, after a short illness, in his eightyseventh year. He studied medicine as an undergraduate at Queen's College, Belfast, and in 1895 obtained First Class Honours in the M.B., B.Ch., B.A.O. examination of the Royal University of Ireland. After holding various House Officer appointments he decided to take up surgery, and in 1902 became a Fellow of the Royal College of Surgeons of England. He then proceeded to Vienna where he spent some years studying ophthalmology and otology. His main life's work was done in Belfast, where he was on the staff of the Royal Victoria Hospital from 1903 until his retirement in 1937 at the age of 65. In 1913 he was appointed lecturer in ophthalmology and otology at the Queen's University of Belfast, a post which he held for 24 years. On the outbreak of hostilities in 1939 he returned to his old hospital post to help to relieve his junior colleagues for service in the armed forces.

Queen's University paid tribute to his long and distinguished services in 1951 by awarding him the degree of M.D. (honoris causa). In the following year he gave a considerable sum of money to the university to be devoted for the furtherance of ophthalmological studies; up to the present this has been expended in the establishment of a periodical lectureship associated with the James Craig Prize.

James Craig was a member of the Ophthalmological Society of the United Kingdom and of the Oxford Ophthalmological Congress, and was a past president of both the Ulster Medical Society and the Irish Ophthalmological Society. To all of these bodies he contributed scientific papers from time to time.

As an ophthalmologist he was exact and methodical, an excellent surgeon and a good teacher. He was well versed in literature and his writings were concise and punctilious. Beneath a somewhat reserved manner he had a keen sense of humour and was one of the most kind and generous of men. His chief recreation was golf, and until recent years he was a regular attender at the Royal Co. Down Golf Club, Newcastle, of which he was Captain in 1943 and 1944.

He is survived by two sons, Dr. Maurice Craig and Mr. Alan Craig.

\section{JOHN DOBSON WARDLE}

Mr. John Dobson Wardle, emeritus professor of ophthalmology in the University of Durham and honorary consulting surgeon of the Royal Victoria Infirmary, Newcastle upon Tyne, died at his home near Haydon Bridge on December 7, 1958, at the age of 90 .

He was born in Gateshead and educated at Aston Grammar School, Market Rasen, Lincs., and later at Durham University College of Medicine, where he qualified in 1891. In 1900 he was appointed ophthalmic surgeon to the old Newcastle Infirmary on the Forth banks. He lectured in ophthalmology in the College of Medicine, and was later appointed professor of ophthalmology in the University of Durham-one of the first chairs in the subject in England. He retired from the Infirmary in 1928 and from his professorship in 1933. 